\title{
SPATIAL MEANINGS OF NA AND SEMANTICALLY RELATED PREPOSITIONS IN MACEDONIAN
}

\author{
Aleksandar Pavlov \\ Ss. Cyril and Methodius University \\ alexandar.pavlov@gmail.com
}

The paper presents a contrastive analysis of the spatial meanings of the preposition $n a$ and its semantic counterparts in Macedonian. Reviewed here are the contexts in which $n a$ assumes similarity of meaning to another preposition. In that respect, a view is presented that the synonymy among prepositions ensues from a shared topology they denote. This necessitates that the preposition in question should code the same position of participants as the preposition of comparison. However, the preposition na shows contextual uniqueness for the functional sense it carries. Whenever contrasted with another preposition in Macedonian, its functional aspect gains salience, whereby na introduces strong functional sense.

Key words: spatial prepositions, semantic nuance, topology, synonymy 


\title{
ПРОСТОРНИТЕ ЗНАЧЕЊА НА ПРЕДЛОГОТ НА И БЛИСКОЗНАЧНИТЕ ПРЕДЛОЗИ ВО МАКЕДОНСКИОТ ЈАЗИК
}

\author{
Александар Павлов \\ Универзитет „Св. Кирил и Методиј“, Скопје \\ alexandar.pavlov@gmail.com
}

Оваа статија претставува контрастивна анализа на просторните значења на предлогот на и блискозначните предлози во македонскиот јазик. Тука се дава осврт на контекстите каде што на би можел да се доведе во една врска на блискозначност со друг предлог. Притоа, се истакнува ставот дека синонимијата меѓу предлозите се должи на заедничките тополошки конфигурации што тие ги изразуваат. Ова значи дека предлогот треба да кодира иста положба на партиципантите како и споредуваниот предлог. Но, она што предлогот на го прави исклучителен при најразлични конфигурации е неговото функционално значење. Секој пат кога тој се сопоставува со друг македонски предлог, до израз доѓ́а функционалниот аспект, при што на во значењето внесува силно функционално значење.

Клучни зборови: просторни предлози, семантичко нијансирање, топологија, синонимија 


\section{Introduction}

This paper uses cognitive framework to explore the spatial semantics of the preposition $n a$ in Macedonian by comparison with its semantic counterparts. This includes the Macedonian prepositions vrz, nad, kaj, kraj, pokraj, vo, pred, po, preku and $z a$, providing contexts wherein these prepositions enter into a relation of synonymy. The aim is to highlight such features which, despite the apparent interchangeability, distinguish the preposition of interest as a separate lexeme. This will point to semantic nuance and reflect current language in use.

Such study arises from the need to provide a more detailed investigation of the semantics of the preposition na. Hence, taking into consideration the study of the preposition na conducted so far by Koneski (Конески 1981), Korubin (Корубин 1990) and Sazdov (Саздов 2002, 2004) and the conclusions thereof, there emerges the need for a more exhaustive semantic analysis of this widely-used preposition. Albeit scarce in number, papers on the preposition $n a$ predominantly tackle its use without seriously delving into the motivation behind the meanings.

Examples are taken from texts of modern fiction and from journalistic articles and columns (mainly in electronic form). The contrastive analysis is supplemented by interpretation of the motivation behind the use, taking into account the spatial and functional aspects of the spatial scene. The aim, therefore, is to show that the polysemy of the preposition's spatial semantics should be viewed in direct relation to the conceptual nature of language and its transformational capacity to carry spatial concepts. This will provide clearer image of the prepositional semantics manifested through the current language use.

\section{Theoretical framework}

As relational expressions, prepositions profile atemporal relation (Langacker 1987), which underlines their (primary) spatial meaning. Given that prepositions indicate the position of one entity relative to another, it can be gathered that prepositions denote locational, that is, topological relation. Space is deemed a fundamental notional category, whereas prepositions are means to its linguistic manifestation. They help conceptualise space and create picture about the arrangement of entities. The environment is processed through our sensory perception into notions that construct our perceived reality. Spatial concepts ensue from external experience, and represent internalisation or cognitive refinement of the sensory-motor experience. Such experiences offer subjective reality limited by one's own (physiological and neurological) capacity to conceptualise the environment (Tyler and Evans 2003). Language does not establish direct relation to reality, but it merely depicts what has been formed by the human conceptual 
system (through concepts and schemes), mediated by one's own body and mind. Our bodies interact with the environment, and the resulting experience creates spatial scenes. They are a product of how the environment is conceptualised; a mental representation of the sensory-motor experience formed by our cognitive apparatus. Conceptualisation of such scenes is closely related to the familiarity with the fundamental spatial and functional relations manifested by entities (gravity, weight, size, purpose, etc.). Thus, spatial relations are closely linked to topology (spatial position and orientation), whereas functional relations point to the purpose of an object, which ensues from its features. In that respect, prepositions linguistically code spatial relations established by the participants.

Although the spatial meaning of prepositions is seen as their primary one, the paper presents an opinion that the spatial scene is not constructed strictly by establishing the spatial relation. Many authors (Coventry et al. 1994; Garrod et al. 1999; Coventry 2003; Tyler and Evans 2003) also stress the relevance of the functional relation. The latter, as already mentioned, is linked to the purpose of entities, that is, it presupposes general familiarity of the physical and social world. Functional relation provides semantic interpretation of spatial prepositions which otherwise falls short of elaboration through topological description. The proximity of one object to another (topology) enables mutual interaction (function). Therefore, these two elements are indubitably merged into a "morphological package" (Langacker 2009).

A relation implies mutual interaction of at least two entities. Such entities in the paper are named trajector (TR) and landmark (LM). A TR is any entity the location of which is established by another referential entity. It is a "figure within a relational profile" (Langacker 1987: 217). The LM is a typically static, larger and more conspicuous entity which provides spatial reference for the TR. A spatial scene can sometimes involve more than one LM (Talmy 2000: 203-214).

The spatio-functional set of semantic features, which ensues from the relations among participants, finds linguistic realisation with prepositions. Prepositions are conceptual bridges that complete the mentally construed spatial scene-they help spatially define the TR in relation to the LM.

\section{The preposition $n a$ and the synonymous Macedonian prepositions}

This section offers elaboration of the spatial meanings of the synonymous prepositions to the extent relevant for establishing a relation of synonymy with $n a$. Also provided are the uses in which the preposition $n a$ is readily replaced with another preposition due to overlap in topology and/or interaction between TR and LM. Given below is comparison between the preposition $n a$ and the prepositions vrz, nad, kaj, kraj, pokraj, vo, pred, po, preku and za. 


\subsection{Comparison between $v r z$ and $n a$}

The closeness of meaning of the two prepositions mainly emanates from the spatial relation they code - placement onto someone or something. Yet, by extension, the vertical aspect in both prepositions seems to dissipate throughout various uses. Although Koneski (Конески 1981: 514) restricts the spatial use of vrz in competition with $n a$, claiming that $v r z$ is rarely used in its spatial sense besides $n a$, there is reason to believe that the two prepositions also exhibit semantic similarity. Such similarity of meaning can be traced in the affectedness of the LM due to its interaction with the TR. Additionally, $v r z$ seems to show stronger implication of affectedness than $n a$, while $n a$ is more neutral in this respect (Бужаровска и Митковска 2010; Bužarovska and Mitkovska 2013). The authors (ibid.), however, continue by pointing out that the prepositions are sometimes interchangeable. This is likely because affectedness is intuitively linked with the topology of the TR and LM. Here, the TR is superposed and it exerts force upon the LM, either through gravitation or directed motion. Examples (1) and (2) below illustrate such interchangeability:

(1) Тој сииеше навален врз масаӣа.

'He slept leaning on the table.'

Се налакӣила на ог̄pagā̄̄a.

'She was leaning her elbows on the fence.'

\subsection{Comparison between nad and na}

The preposition nad in Macedonian primarily conveys superposition (Monolingual Dictionary of Macedonian Language, MD; Dictionary of the Macedonian Language with Serbo-Croatian Interpretations, DML). Such spatial arrangement also entails alignment between the TR and LM. Although the prototypical meaning excludes contact (detached superposition), there are uses in which the vertical distance between the TR and LM allows flexibility regarding the feature alignment, encompassing the feature contact (attached superposition) (Митковска и Бужаровска 2011; Mitkovska and Bužarovska 2012). Owing to this topological similarity, some contexts allow the two prepositions to enter into a relation of synonymy. Any time prepositions are contrasted, this being no exception, the selection of a particular preposition prompts different profiling of the spatial scene. Prototypical uses of the preposition nad emphasise the feature superposition, with degree of layeredness, while the preposition $n a$ accentuates coincidence and contact (direct or mediated support). In that respect, their interchangeability favours contexts that include vertical stack-up of objects. Example (3a) underlines superposition of participants, whereas ( $3 b$ ) denotes mediated support. Also note the 
alternative formulation of the Macedonian folk riddle in example (4). Example (4b) underlines the feature coincidence.

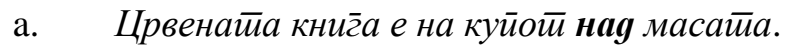
'The red book is on the pile above the table.'

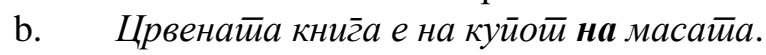
'The red book is on the pile on the table.'

(4) a. Црно мече наg ог̄ан клече.

b. Ц Црно мече на ог̃ан клече.

'Black bear cub crouches over the fire.'

\subsection{Comparison between $k a j$ and $n a$}

The spatial meaning of the preposition kaj in Macedonian is readily associated with proximity or "location near someone or something, or heading towards reaching such location" (Конески 1981: 517). Sazdov (Саздов 2004: 222), however, points out that in competition with compounds of $k a j$ and another preposition, the preposition $k a j$ has retained only the static sense. Semantic similarity with the preposition $n a$ can be traced precisely when depicting static scenes, where TR and LM coincide in time and space. The two prepositions show synonymy strictly with proper names of localities, but not in the general sense, where the LM is just any kind of building or object. The LM thereby denotes functional space with toponymic value. In addition, by using a proper name (locality as LM), a place may acquire referential dominance over other places in the surrounding space. But synonymy, in this respect, does not entail utter and complete interchangeability. The preposition $\mathrm{kaj}$ introduces toponymicity to the syntagm, whereas the preposition $n a$ underlines the functionality of space. ${ }^{2}$ The latter puts emphasis on the activity taking or about to take place on the given location. This is illustrated in the following examples:

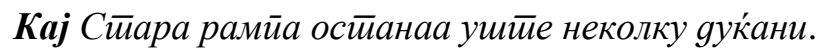
'There are only a few shops left at Stara Rampa.'

Искриен авйобус на ЈСП на Рекоря во Скойје. 'Public city bus demolished at Rekord in Skopje.'

\footnotetext{
${ }^{1}$ Since riddles are culturally determined, providing translation can be a real bear. This one loosely translates to: "What begins with $\mathrm{T}$, ends with $\mathrm{T}$ and has $\mathrm{T}$ in it?"

${ }^{2}$ This section presents "toponyms", i.e., places in the City of Skopje which are widely known among people and therefore perceived as authentic locations.
} 


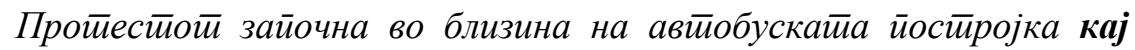
Југ̄одрво.

'The protest began from near the bus station at Jugodrvo.'

Се чекаме во девей на Кайче.

'See you at nine at Kapče.'

\subsection{Comparison of kraj and pokraj with na}

Prepositions treated in this section also convey proximity. But unlike Koneski (Конески 1981: 517), who gives recycled and overgeneralised definition of kraj, Sazdov (Саздов 2004: 227) provides a more elegant formulation: "at the very edge, on the periphery of an expanse." The semantic closeness between the prepositions $n a$ and $k r a j$ ensues from the feature proximity. In that respect, the preposition kraj is functionally more neutral and it merely profiles proximity. The preposition $n a$, on the other hand, makes strong implication of coincidence and contiguity, whereby participants form scenic unity and establish incessant link (cf. examples 9a and 9b).

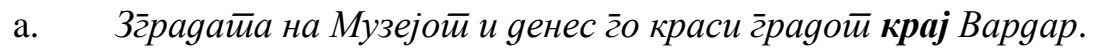
'The Museum building still embellishes the city by the Vardar River.'

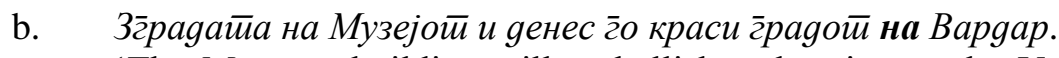
'The Museum building still embellishes the city on the Vardar River.'

Similarly related to the proximity sense is the preposition pokraj, mainly used for dynamic contexts (hence the prefix po-), although it can also denote occupation of space "along something" (DML). Given below are uses arising from static spatial scenes, allowing interchangeability between the prepositions pokraj and na. Here, despite TR's immobility, the spatial scene creates the impression that the TR is moving along a fictive path. ${ }^{3}$

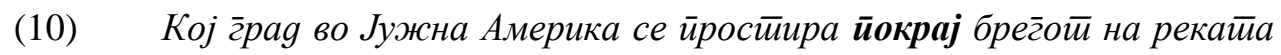
Ла Плайа?

'Which city in South America extends on the coast of the River Plate?'

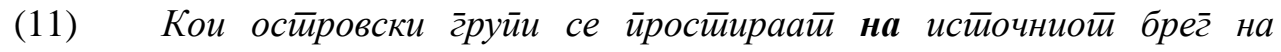
Африка?

'Which island groups extend along the eastern coast of Africa?'

\footnotetext{
${ }^{3}$ Such dynamisation of the static spatial scene reflects what Langacker (1990) calls subjectification.
} 


\subsection{Comparison between $v o$ and $n a$}

Viewed in their general sense, vo conveys containment, and $n a$ denotes coincidence and support (through direct or mediated contact). Additionally, na evokes twodimensional space or space with no distinct dimensions, while with vo, space is more clearly delineated and it has distinct dimensions (Саздов 2004: 201). But the relative semantic closeness of the two prepositions stems from the shared etymology (Skok 1973).

Seliverstova (Селиверстова 2000), for example, maintains that the choice between $n a$ and $v o$ hinges on the means of nominating the two-dimensional space, i.e. whether dimensionality is lexically signified. Hence, if LM's active zone ${ }^{4}$ consists of a surface and lateral sides rising above that surface, the preposition vo is used (долина 'valley', клисура 'ravine'). But if the lateral sides are ignored when construing the spatial scene, the preposition $n a$ is used (на/во улица 'on/in the street', but: во сокакой 'in the alley'). Vo is regularly used when the referent is conceptualised as a distinctive world with its own flora and fauna, nature, and climate, with entities located in it (шума 'forest', океан 'осеаn').

The preposition $n a$ codes relations wherein the TR and LM display wide geometrical flexibility. It is in this aspect where one finds the common ground for the two prepositions. Thus, despite coding coincidence, $n a$ in such contexts also implies interiority:

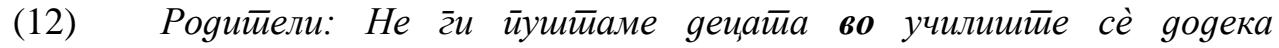

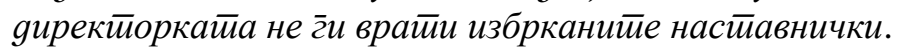

'Parents: We are not letting our children in school until the headmistress rehires the laid-off teachers.'

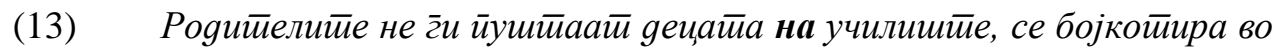
„11 Окимомври“.

"Parents won't let children in school - boycott in "11 Oktomvri" Elementary.'

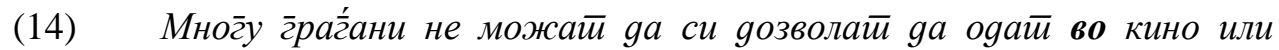

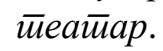

'Many citizens can't afford to go to the cinema or the theatre.'

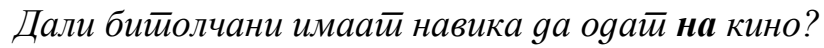

'Do people from Bitola tend to go to the cinema?'

The examples given above indicate that the activity occurs within closed space, carrying the implication of purpose (to study in school). The preposition vo

\footnotetext{
${ }^{4}$ Refers to a part or area of the LM in direct interaction with the TR (Radden and Dirven 2007: 303; Langacker 2008: 272).
} 
underlines the interior location, while $n a$ underscores the activity within a designated space. Hence, common topology of participants endorses interchangeability. If, on the other hand, the spatial scene depicts an outdoor cinema, there would be no justification to use the preposition $v o$, but only $n a$.

\subsection{Comparison between pred and na}

The preposition pred denotes a position before or in front of something (DML). Its use presupposes proximity of the participants (TR and LM). Furthermore, this imposes two topological restrictions: TR assumes specific position relative to LM, and LM and TR exhibit specific orientation. The former implies that the TR is always positioned in front of the LM. As for the latter, the configuration dictates that the LM should always face the TR without imposing orientational restrictions on the TR. Therefore, although the TR spatially occurs in front of the LM, it shows flexibility in regard to orientation. However, a relation of synonymy in this prepositional pair emerges only in configurations when TR and LM are facing each other. Accordingly, TR's orientation carries functional implications, whereby one can discern the intent to establish functional link with the LM-hence the necessity to be oriented towards it. Here, it seems, contact is ignored. Moreover, it should be underlined that the relative interchangeability is attainable strictly with animate TRs, since functional link can only be established when they are conscious agents. This is presented in examples (16) and (17). But, as already mentioned, besides conscious agent, interchangeability necessitates orientation towards LM, i.e. implied intent to act in the direction of the LM, even if it does not present the ultimate target. In example (18), the TR is located behind LM's canonically conceptualised front side (на врайайа 'at the door'). By using pred in this context, the TR would be "relocated" to a position on the back side of the LM-which is not the case in the previous two examples-and therefore there is no synonymy. In example (19), the adverbial provides additional hint about the direction of movement to a position in front of the LM. Furthermore, note the alternative use of preposition in the second verse of this folk song (19b). Despite the interchangeability, the preposition pred strongly emphasises the spatial aspect of the scene, while the preposition $n a$ alludes to the functionality of the LM. To sum up, the overlap in topology (as a requisite for synonymy) selects for a specific LM type, whereas the canonical position of the TR ensures proximity with orientation

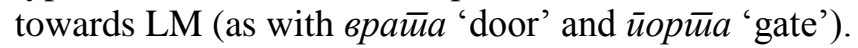

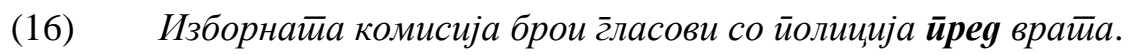

'The election commission is counting votes with the police at the door.'

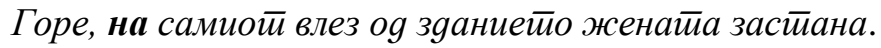

'At the top, right at the entrance to the memorial, the guide stopped.' 


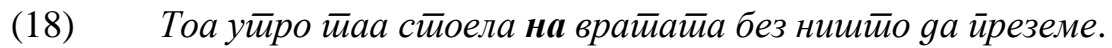
'That morning she stood at the door without doing anything.' (*üpeg вратата)

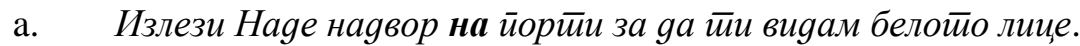 'Come out Nade to the gates so I can see your white face.'
b. Излези Наgе наgвор йреg йорйи за gа йи вияам белойо лище. 'Come out Nade to the gates so I can see your white face.'

Examples given below point to restrictions on the synonymous use of the preposition $n a$ in contexts where the TR is inanimate (example 20) or animate but not readily perceived as a conscious agent (example 21). Moreover, it seems that English uses do not select for a different preposition regarding TR animation and consciousness:

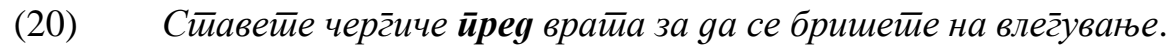

'Place a doormat at the door to wipe shoes on your way in.'

(* на врата)

(21) Преg влезнайа врайа на еgна жена оg Флорияа се йојавил алиг̄айор.

'An alligator appeared at the front door of a woman in Florida.'

(* на влезната врата)

\subsection{Comparison of po and preku with na}

The prepositions $n a$ and preku semantically approach each other in terms of the feature distribution. With po, the preposition na exhibits semantic similarity in two respects: distribution and directionality. As regards distribution, Bužarovska and Mitkovska (Бужаровска и Митковска 2010) highlight the similarity of meaning among the prepositions vrz, preku, po and na. They continue to point out that the prepositions po and preku imply overall coverage of LM's surface, while with $n a$, such coverage although not excluded, is backgrounded. See the similar uses of preku and $n a$ in examples (22-25):

(22) Знамейо се расйосла йреку итрибинииее.

'The flag spread out over the terraces.'

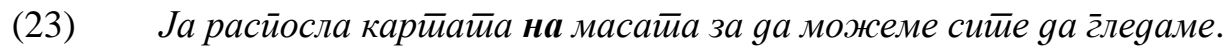

'He spread out the map on the desk so we could all see.' 
(24) Начин на уйойреба: Се нанесува йреку зярави, gобро исчистиени иовриини.

'Directions for use: Apply over firm, well-cleaned surfaces.'

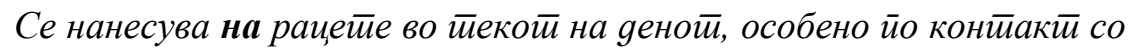
воga.

'Apply on the hands in the day, especially after contact with water.'

Moreover, the prepositions po and na are relatively interchangeable only in contexts where the LM represents a surface; po emphasises scatteredness of objects (TRs) upon a surface (LM), but na primarily denotes location onto a surface:

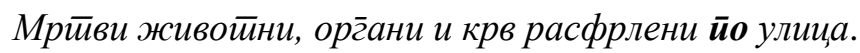

'Dead animals, organs and blood scattered over the street.'

Праскийе завршија расфрлани на улища и фрлени на gейонија.

'The peaches ended up scattered on the street and thrown in the landfill.'

The following example portrays the subtle difference between the prepositions $n a$ and po when denoting distribution. In contexts where the LM cannot be conceptualised as a surface, but instead, containment (three-dimensional space) is implied, the use of po is strictly favoured. Also, with the implication of distribution, LM denotation is regularly realised in the plural form:

Убаво ни беше ког̄а йиевме ӣо барови и йо дискойеки.

'We had a good time drinking in bars and in night clubs.'

(*на дискотеки / *на кафулиња)

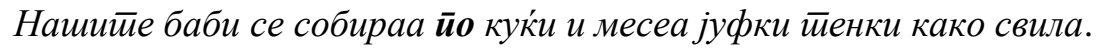

'Our grandmothers would gather in homes to make yufka as thin as silk.'

(* на куќи)

The second aspect refers to directionality, that is, activity directed at the LM. These uses impart TR's intent without necessarily realising contact. While contact is contextually implicated, prepositions thus used accentuate the path and not the target. Hence, contact in such uses wades on account of purpose (Арсова 2015). Here, in spite of the observed synonymy, the functional aspect promotes variation in meaning: the preposition $n a$ stresses the attempt to reach a target, whereas po underlines the repetitiveness of action. Examples of this are provided in the text below. Note the alternative formulation of the proverb in example (30) still used in Macedonian.

(30) а. Ако не можеш ӣо маг̄арейо уgри йо самарой.

b. Ако не можеш на маг̈арет̄о уяри на самарой.

'He that cannot beat the donkey, beats the saddle.' 


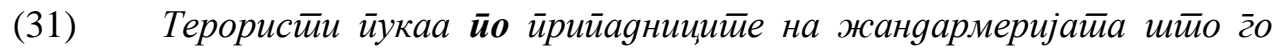
иимитеиеа конвојой.

'Terrorists fired on members of the gendarmerie who were protecting the convoy.'

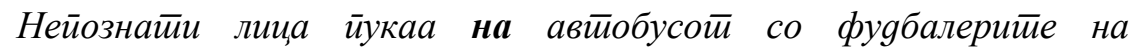
Фенербахче.

'Unknown persons fired on the bus carrying Fenerbahçe football players.

All this shows how the LM imposes functional restrictions on uses expressing distribution and directionality. And while with distribution the LM represents twodimensional space or surface (example 33), with directionality it represents an object or a reified abstraction (target), as in example (34):

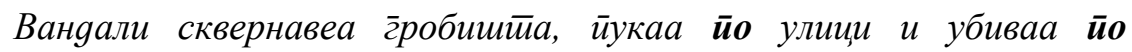
кафулиња.

'Vandals desecrated cemeteries, fired in the streets and killed in coffee bars.'

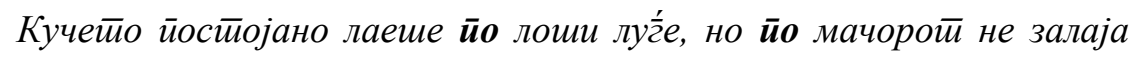
ниеднаш.

'The dog constantly barked at bad people, but not even once at the tomcat.'

\subsection{Comparison between $z a$ and $n a$}

Functional aspect central to the relation of synonymy between the prepositions $n a$ and $z a$ is the physical link between TR and LM, denoting "point of attachment, contact, joining one thing to another" (DML). Participants in this spatial relation establish either direct contact, with TR at the LM, or mediated link, with TR in LM's proximity. Moreover, the semantics of the concomitant verb reinforces the construing of spatial scenes that depict TR's constrained mobility (врзува 'tie', обесува 'hang'). The semantic nuance for the two prepositions pertains to the following: $z a$ denotes the site of placing such constraint upon the TR (LM's active zone), and $n a$ implies spatial coincidence, whereas the LM restricts TR's mobility within its sphere of functional influence. ${ }^{5}$ This is illustrated in examples (35) and (36).

\footnotetext{
${ }^{5}$ The concept represents a region or range within which the LM establishes influence over the TR, thereby spatially defining it (Coventry et al. 1994). Radden and Dirven (2007: 303) use the term region.
} 
Нѐ оgнесоа во лозјейо, нѐ врзаа за еgна кајсија, нѐ иеейаа.

'They took us to the vineyard, tied us to an apricot tree and beat us.'

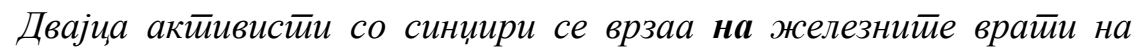

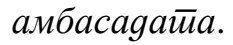

'Two activists chained themselves to the iron gates of the embassy.'

\section{Overview of synonymy}

Table 1 below summarises the topological similarities and functional differences between the preposition $n a$ and its semantic counterparts in Macedonian. This overview portrays the polysemic potential of the preposition $n a$; it achieves interchangeability by construing spatial scenes that are shared with other prepositions, albeit, due to the functional aspect, the meaning is nuanced.

Table 1. Overview of synonymy between $n a$ and its semantic counterparts in Macedonian

\begin{tabular}{lcc}
\hline & TOPOLOGICAL & FUNCTIONAL DIFFERENCE OF \\
& SIMILARITIES & $\boldsymbol{N A}$ \\
\hline $\boldsymbol{v} \boldsymbol{r z}$ & position onto LM & weaker implication of pressure \\
$\boldsymbol{n a d}$ & position onto LM & weaker implication of superposition \\
$\boldsymbol{k} \boldsymbol{a j}$ & proximity & functionality of space \\
$\boldsymbol{k} \boldsymbol{r a j}$ & proximity & TR and LM constitute functional unity \\
$\boldsymbol{p o} \boldsymbol{k r a j}$ & fictive path & TR and LM constitute functional unity \\
$\boldsymbol{v} \boldsymbol{o}$ & interior coincidence & interior activity \\
$\boldsymbol{p r e d}$ & position in front of LM & TR establishes functional link with LM \\
$\boldsymbol{p o}$ & surface contact; & neutrality in distribution; \\
& directionality & neutrality in repetitiveness \\
$\boldsymbol{p r e k \boldsymbol { u }}$ & surface contact & neutrality in LM coverage \\
$\boldsymbol{z a}$ & spatial coincidence & controlled location \\
\hline
\end{tabular}

\section{Conclusion}

The semantics of a given preposition does not boil down to occupying a stringent niche in language. Synonymy, therefore, should be seen through the prism of semantic similarity, with prepositions carrying their own spatio-functional set of semantic features. This similarity is actualised only in certain contexts, in which spatial meaning is semantically nuanced. Even so, accepting semantic equivalence would be promoting redundancy, which betrays the language economy principle.

In view of the abovementioned, the contextually-determined interchangeability of spatial prepositions ensues from the shared topology they denote. Hence, the 
preposition $n a$ enters into a relation of synonymy with another preposition only when coding the same topology of participants. But despite this overlap, the preposition $n a$ generally introduces strong functional sense. Thus, in comparison with $v r z, n a$ exhibits greater neutrality regarding the affectedness of LM supporting the TR. With nad they both denote layered superposition, but na highlights coincidence and contact. Showing strong implication of proximity with kaj, the preposition $n a$ depicts the functionality of space. And although the proximal sense permeates synonymous uses of kraj, pokraj and na, the third preposition makes strong implication of coincidence and contiguity. When juxtaposed with vo, interiority is evoked, but $n a$ tilts towards the activity within closed space. Despite the spatial commonality with pred in proximity and orientation, $n a$ underlines the functionality of the LM. And whereas the triad of preku, po and na implies coverage of LM's surface, such feature with $n a$ is less salient. Moreover, interchangeability between $p o$ and $n a$ is realised in two aspects: distribution and directionality. As for distribution, instead of depicting scatteredness of objects like $p o, n a$ is somewhat more neutral in presenting TR's position onto the LM. With the second aspectdirectionality - $n a$ focuses on the attempt to reaching the LM (target), without clear contact, thus making a different implication to the repetitiveness of action conveyed by $p o$ in this respect. Finally, both $z a$ and $n a$ show resemblance of meaning when profiling restriction of TR's mobility, whereby the latter affirms LM's sphere of functional influence, and not the point of attachment (as with $z a$ ).

\section{References}

Bužarovska, E., and Mitkovska, L. (2013). From physical to abstract affectedness: prepositions $v r z$ and vărhu in Balkan Slavic. In Šarić, L. (ed.) Space in South Slavic, Oslo Studies in Language 5 (1): 35-60.

Coventry, K., Carmichael, R., and Garrod, S. (1994). Spatial Prepositions, Object-Specific Function, and Task Requirements. Journal of Semantics 11: 289-309.

Coventry, K. (2003). Spatial prepositions, spatial templates, and 'semantic' versus 'pragmatic' visual representations. In E. van der Zee and J. Slack. (eds.). Proceedings of the 26th Annual Conference of the Cognitive Science Society, 1381-86. Lawrence Erlbaum Associates: Mahwah, NJ.

Garrod, S., Ferrier, G., and Campbell, S. (1999). In and on: investigating the functional geometry of spatial prepositions. Cognition, 72: 167-189.

Langacker, R. W. (1987). Foundations of Cognitive Grammar, vol. 1. Stanford: Stanford University Press.

Langacker, R. W. (1990). Subjectification. Cognitive linguistics, 1: 5-38.

Langacker, R. W. (2009). Reflections on the functional characterization of spatial prepositions. Belgrade English Language and Literature Studies (BELLS) vol. 1, 9-35.

Mitkovska, L. and Bužarovska, E. (2012). The preposition and the prefix nad in South Slavic languages with emphasis on Macedonian. Jezikoslovlje, 13 (1): 99-139.

Radden, G. and Dirven, R. (2007). Cognitive English Grammar, vol. 2. Amsterdam: John Benjamins. 
Skok, P. (1973). Etimologijski rječnik hrvatskoga ili srpskoga jezika. Knjiga druga. Zagreb: Jugoslavenska akademija znanosti i umjetnosti.

Talmy, L. (2000). Toward a Cognitive Semantics, vol. 1. London: MIT Press.

Tyler, A. and Evans, V. (2003). The Semantics of English Prepositions. Cambridge: Cambridge University Press.

Арсова, С. (2015). Преgлозийе ӣo, ирреку и низ за изразување хоризонйална gимензија

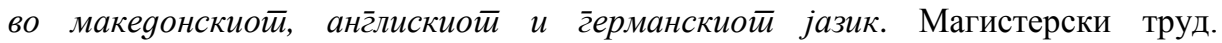
Филолошки факултет „Блаже Конески“, УКИМ, Скопје.

Бужаровска, Е., Митковска, Л. (2010). Анализа на предлогот врз од когнитивен аспект. Прилози XXXV/2: 137-150.

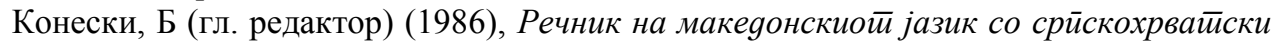
йолкувања [Dictionary of the Macedonian Language with Serbo-Croatian Interpretations]. Скопје: Македонска книга.

Конески, К (гл. редактор), (2006). Толковен речник на макеgонскиоти јазик [Monolingual Dictionary of Macedonian Language], том III. Скопје: Институт за македонски јазик „Крсте Мисирков“.

Корубин, Б. (1990). Употребата и значењата на предлогот на во современиот македонски јазик. На македонско граматички теми. Скопје: Институт за македонски јазик „Крсте Мисирков“.

Митковска, Л., Бужаровска, Е. (2011). Предлогот наg од когнитивен аспект. Во XXXVII Научна конферениија на меѓуунаровниой семинар за макеgонски јазик,

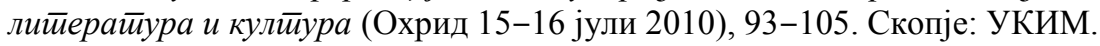

Саздов, С. (2002). Предлозите во македонскиот јазик од семантичка гледна точка. Во: ХХVIII научна конференција, 159-167. Скопје: УКИМ.

Саздов, С. (2004). Семанииччко зборообразување во макеgонскиой сӣанgарgен јазик. Докторски труд. Скопје: Филолошки факултет „Блаже Конески“, УКИМ.

Селиверстова, О. Н. (2000). Семантическая структура предлога на. Исслеgования йо семанйике йреgлог̄ов. Д. Пайар, О. Н. Селиверстова (уред), 198-242. Москва: Русские словари. 